\title{
Análisis sobre la influencia de la densidad en la termografía de infrarrojos y el alcance de esta técnica en la detección de defectos internos en la madera
}

\section{Analysis of the influence of density on infrared thermography and of the scope of this technique in the detection of internal defects in wood}

\author{
C. Rodríquez-Liñán ${ }^{(*)}$, M. J. Morales-Conde(*), P. Rubio-de Hita(*), F. Pérez-Gálvez(*)
}

Recepción/Received: 1-X-10

Aceptación/Accepted: 7-III-11

\section{RESUMEN}

En el presente artículo se muestran los resultados obtenidos en una fase de laboratorio al tratar de determinar el alcance de la termografía de infrarrojos en la detección de defectos internos en la madera y, por otro lado, cómo interviene la densidad de este material sobre la temperatura superficial mostrada en un termograma. Para ello se ha desarrollado un trabajo experimental donde se han controlado una serie de parámetros ambientales y de trabajo (temperatura ambiente, humedad relativa, distancia al objetivo...), y se ha sistematizado el proceso utilizando piezas de distintas especies de madera (distintas densidades) y diseñando una serie de probetas donde se han analizado varias casuísticas posibles en cuanto a tamaño y posición interna de los daños. Análogamente, sobre estas probetas se ha estudiado el efecto que produce sobre la imagen termográfica un incremento de humedad interna en el defecto asociada normalmente a los fenómenos de pudrición de la madera.

Palabras clave: termografía de infrarrojos, madera, densidad, detección de defectos internos, deterioro.

\section{SUMMARY}

This paper shows the results of a laboratory phase for the determination of the 1limits of infrared thermography in detecting internal defects in wood and, furthermore, it analyses how the density of this material can influence the surface temperature displayed in a thermogram. To this end, experimental work is carried out whereby a series of work and environmental parameters are monitored (such as environmental temperature, relative humidity, distance to target), and the process is systematized by using pieces of different wood species (different densities) and by devising a set of samples for which various possible cases are analysed in terms of size and internal position of the damage. Similarly, using these samples, a study has been conducted on the effect on the thermal image produced by an increase of humidity inside the defect phenomena normally associated with wood decay.

Keywords: infrared thermography, wood, density, detection of internal defects, decay.
(*) Universidad de Sevilla (Sevilla, España).

Persona de contacto/Corresponding author: rlinan@us.es 


\section{INTRODUCCIÓN}

La madera es un material que, por su trabajabilidad y propiedades mecánicas, ha sido muy utilizada a lo largo de la historia como material estructural. No obstante, debido a su naturaleza biológica, sus propiedades pueden verse alteradas. Patologías de origen biótico como los hongos xilófagos o los insectos sociales (termitas) asociadas a un incremento de humedad pueden degradar su estructura provocando una pérdida de densidad y un descenso de su resistencia.

Esta problemática, muy extendida en estructuras antiguas, y la necesidad de localizar las zonas afectadas, cuando el deterioro no es superficial, nos ha llevado a experimentar con técnicas que posibiliten el desarrollo de una metodología de trabajo para enfrentarnos a tales situaciones, con el objetivo de establecer un diagnóstico adecuado del estado de deterioro de una estructura. En ese contexto se encuadra, a priori, la termografía de infrarrojos, como técnica de inspección no destructiva que permite localizar defectos situados debajo de la superficie sin necesidad de establecer un contacto con la superficie a inspeccionar.

Actualmente, esta técnica tiene un campo de aplicación muy extenso utilizándose como método de evaluación e inspección en muchos ámbitos. En la construcción, su papel se reserva fundamentalmente para la detección de humedades y análisis sobre el comportamiento energético de edificios y sus instalaciones $(1,2)$, apareciendo algunos trabajos sobre la detección de grietas en estructuras de hormigón o como técnica de control de calidad de materiales (piedra, cerámica) (3). Todo esto nos lleva a plantearnos su aplicabilidad en el estudio de la madera como material estructural presente en obras de rehabilitación.

En este sentido, se está investigando la aplicación de la termografía en la madera para ilustrar el proceso de daño en las estructuras a través de los mapas tensionales extraídos de la disipación de calor en las zonas cargadas (4). Otras líneas de estudio analizan la posibilidad de emplear la termografía como técnica de ensayo no destructiva para detectar humedades o pérdidas de densidad internas provocadas, en su mayoría, por pudriciones o ataques de termitas (5-8). Así, debemos reseñar que, paralelamente, en Norteamérica se están realizando estudios para localizar la actividad de termitas subterráneas en edificios históricos (9).

Con todo esto, el objetivo de este trabajo es determinar el alcance y las posibilidades reales de aplicación de la técnica para la detección de defectos internos en la madera tanto en condiciones de laboratorio como, para en una segunda fase, técnica de inspección y caracterización in situ de una estructura.

\section{INTRODUCTION}

Wood is a material which, owing to its workability and mechanical properties, has been widely used throughout history as a structural material. However, due to its biological nature, these properties can be affected by various factors. Pathologies of a biotic origin, such as fungi and social insects (termites), associated with an increase of humidity degrade its structure thereby provoking a loss of density and a decrease in the resistance of the wood.

This problem, widespread in ancient structures, together with the need to locate affected areas which have no damage visible on the surface, has led us to experiment with techniques that enable the development of a working methodology to deal with such situations, in order to establish an accurate diagnosis of the state of deterioration of a structure. In this context, infrared thermography is found to be a highly suitable as a nondestructive and non-contact inspection technique that can locate internal defects.

Nowadays, this technique has a very wide scope as a method of evaluation and inspection in many areas. In construction, its role is mainly reserved for the detection of humidity and analysis of the energy performance of buildings and their facilities $(1,2)$. In some work, this technique is used to detect cracks in concrete structures and as a quality control technique for certain materials (stone, ceramic) (3). All this leads us to consider its applicability in the study of wood as a material that is found in rehabilitation work.

In this regard, research is being carried out on the application of thermography to wood to show the damage process in structures through tension maps which are extracted from the heat dissipation of loaded areas (4). Other studies discuss the possibility of using thermography as a non-destructive testing technique to detect humidity or internal density losses caused mostly by decay or termite attack (5-8). At the same time, in North America, studies are being conducted to locate the activity of subterranean termites in historical buildings (9).

The objective of this study is to determine the scope and the real possibilities of the application of the technique for the detection of internal defects in wood, in both laboratory conditions and, in a second phase, as an in situ inspection and characterization technique of a structure. 


\section{MATERIALES Y MÉTODOS}

\subsection{Principios físicos}

La termografía está basada en el principio físico de transmisión de calor por radiación. La ley de Planck calcula la potencia radiada por un cuerpo negro, por unidad de área, y unidad de longitud de onda. La integral sobre todo el espectro de longitudes de onda se define como ley de Stefan-Boltzmann y viene definida mediante la ecuación [1] donde a partir de la energía radiada por un cuerpo en el rango de infrarrojo se puede obtener su temperatura superficial.

\section{MATERIALS AND METHODS}

\subsection{Physical principles}

Thermography is based on the physical principle of heat transfer by radiation. Planck's law calculates the power radiated by a black body, per unit of area, and unit of wavelength. The integral over the entire spectrum of wavelengths is defined as the Stefan-Boltzmann law and is expressed by equation [1], where, from the energy radiated by a body in the infrared range, its surface temperature can be obtained.

$$
\mathrm{Q}_{\text {emitida }}=\varepsilon \cdot \sigma \cdot \mathrm{A}_{\mathrm{S}} \cdot \mathrm{T}_{\mathrm{S}}^{4} \text { (Vatios) }
$$

$\varepsilon \quad$ Emisividad de la superficie.

o $5,67 \cdot 10^{-8} \mathrm{~W} / \mathrm{m}^{2} \cdot \mathrm{K}^{4}$ la constante de Stefan-Boltzmann.

$A_{S}$ Área de la superficie.

$\mathrm{T}_{\mathrm{S}}$ Temperatura de la superficie.

No obstante, la radiación que llega a la cámara termográfica es la total saliente del objeto (suma de la radiación emitida y reflejada) y, en función de la emisividad del cuerpo y de la temperatura ambiente reflejada, calcula la radiación emitida (definida en la ecuación [1]). Para ello considera que el cuerpo tiene una emisividad constante en el rango de infrarrojos. Así, para que el resultado de la medición sea fiable el valor de la emisividad debe estar próximo a la unidad de forma que se reduzca la componente reflejada del ambiente. La madera tiene una emisividad de 0,9 por lo que los resultados obtenidos son aceptables.

Las características de esta radiación radican en las propiedades térmicas del material: calor específico, conductividad y difusividad térmica. Cada material tendrá un comportamiento diferente en función de estas propiedades y emitirá una cantidad de energía que se traduce en temperatura superficial del cuerpo.

El calor específico de la madera $C p\left(\mathrm{~J} / \mathrm{kg}{ }^{\circ} \mathrm{C}\right)$, cantidad de calor necesario para incrementar su temperatura un grado por unidad de masa, es independiente de la especie y de la densidad pero varía con el contenido de humedad $(5,7)$.

Por otro lado, su conductividad térmica $k\left(\mathrm{~W} / \mathrm{m}^{\circ} \mathrm{C}\right)$, cantidad de calor que pasa a través de la unidad de superficie para un cuerpo de una unidad de espesor en una unidad de tiempo, es baja $0,17 \mathrm{~W} / \mathrm{m}^{\circ} \mathrm{C}$. Esto es debido a su estructura porosa y está afectada por la densidad, el contenido de humedad, la dirección de la fibra, las irregularidades estructurales y la temperatura $(5,7)$.

Finalmente, la difusividad térmica $\alpha\left(\mathrm{m}^{2} / \mathrm{s}\right)$, obtenida de los parámetros anteriores, representa cuán rápido se difunde el calor por un material. La madera tiene un $\varepsilon \quad$ Surface emissivity.

$\sigma \quad 5.67 \cdot 10^{-8} \mathrm{~W} / \mathrm{m}^{2} \cdot \mathrm{K}^{4}$; the Stefan-Boltzmann constant.

$A_{s}$ Surface area.

$T_{S}$ Surface temperature.

However, the thermographic camera receives the total radiation coming from the object (sum of emitted and reflected radiation) and, depending on the emissivity of the body and reflected ambient temperature, calculates the emitted radiation (defined in equation [1]). To this end, a constant emissivity in the infrared range for the body is considered. The emissivity value should be close to unity so as to reduce the reflected component, and therefore the measurement result can be taken as reliable. Wood has an emissivity of 0.9 , and hence the results are acceptable.

The characteristics of this radiation depend on the thermal properties of the material: specific heat, conductivity and thermal diffusivity. Each material behaves differently depending on these properties and emits an amount of energy which is translated into the surface temperature of the body.

The specific heat of wood, $\mathrm{Cp}\left(\mathrm{J} / \mathrm{Kg}^{\circ} \mathrm{C}\right)$, is the amount of heat needed to raise its temperature one degree per unit of mass, and is independent of wood species and density, but varies with moisture content $(5,7)$.

On the other hand, its thermal conductivity, $\mathrm{k}\left(\mathrm{W} / \mathrm{m}^{\circ} \mathrm{C}\right)$, i.e. the amount of heat passing through the unit area for a body of unit thickness in unit time is low: $0,17 \mathrm{~W} / \mathrm{m}^{\circ} \mathrm{C}$. This is due to the fact that wood has a pore structure and is also affected by many parameters such as density, moisture content, the direction of the grain, structural irregularities, and temperature $(5,7)$.

Finally, the thermal diffusivity, $\alpha\left(\mathrm{m}^{2} / \mathrm{s}\right)$, obtained from the above parameters, represents how fast heat diffuses through a material. Wood has a low thermal diffusivity 
valor de difusividad térmica bajo: $0,13 \times 10^{-6}$, por lo que, en su mayor parte, el calor es absorbido por el material y una pequeña cantidad es conducido. Varía con la densidad y con el contenido de humedad $(5,7)$.

\subsection{Equipos utilizados}

Todos los ensayos de termografía se realizaron con una cámara FLIR que trabaja en la banda espectral de 7,5 a $13 \mu \mathrm{m}$ y tiene una sensibilidad térmica de $0,10{ }^{\circ} \mathrm{C}$ a $30{ }^{\circ} \mathrm{C}$ con una precisión de $\pm 2{ }^{\circ} \mathrm{C}, \pm 2 \%$. El tipo enfoque es manual y tiene un campo de visión $23^{\circ} \times 17^{\circ}$ y una distancia mínima de enfoque de 0,3 m. El tipo de detector es un microbolómetro no refrigerado (FPA) y su resolución es de 320 x 240 píxeles.

Para la estimulación térmica de las probetas se ha empleado una estufa de secado y esterilización marca Selecta. Esta estufa tiene una capacidad de 150 litros con unas dimensiones interiores de $50 \times 60 \times 50 \mathrm{~cm}$. Consta con un termostato y un termómetro analógicos. Su rango de temperaturas regulables oscila desde los 40 hasta los $250{ }^{\circ} \mathrm{C}$ con una estabilidad de $\pm 0,5{ }^{\circ} \mathrm{C}$ y homogeneidad de $\pm 2 \%$.

Las determinaciones de contenido de humedad se han realizado con un xilohigrómetro digital de la marca Protimeter modelo Surveymaster SM.

\subsection{Ensayos realizados}

La planificación de la fase experimental ha tenido en cuenta los objetivos perseguidos en cada ensayo y se ha subdividido en varias etapas.

\subsubsection{Análisis sobre la influencia de la densidad de la madera en su temperatura superficial}

Para realizar este ensayo se han empleado 15 probetas de madera de $2 \times 2 \times 30 \mathrm{~cm}$ de diferentes especies (roble, álamo, pino, cedro y eucalipto) determinando sus densidades medias y su contenido de humedad (11$13 \%$ ) mediante xilohigrómetro digital.

En una primera fase del ensayo se ha tomado la imagen termográfica de las piezas a temperatura ambiente sin aplicar ninguna fuente de estimulación externa y corrigiendo, previamente, los valores de emisividad y temperatura ambiente reflejada.

En una segunda fase, se han estimulado térmicamente las probetas en una estufa a $80^{\circ} \mathrm{C}$ durante 30 minutos. A continuación, se han extraído de la estufa y se ha realizado un seguimiento del proceso de enfriamiento tomando imágenes termográficas cada 30 segundos durante 40 minutos. value: $0.13 \times 10^{-6}$, which means that most of the heat is absorbed by the material and only a small amount of heat is conducted. Thermal diffusivity varies with the density and moisture content $(5,7)$.

\subsection{Equipment used}

All thermographic tests were performed with a thermalimaging FLIR camera which works in the spectral band from 7.5 to $13 \mathrm{Im}$ and has a thermal sensitivity of $0.10^{\circ} \mathrm{C}$ to $30^{\circ} \mathrm{C}$ with a precision of $\pm 2{ }^{\circ} \mathrm{C}, \pm 2 \%$. The focus is manual and has a field of vision of $23^{\circ} \times 17^{\circ}$ and a minimum focusing distance of $0.3 \mathrm{~m}$. The detector is an uncooled microbolometer (FPA) whose resolution is $320 \times 240$ pixels.

For the thermal stimulation of the samples, a drying and sterilization oven of the Selecta brand was used. This oven has a capacity of 150 litres with interior dimensions of $50 \times 60 \times 50 \mathrm{~cm}$, and is equipped with an analogue thermostat and thermometer. Its adjustable temperature range varies from 40 to $250 \circ \mathrm{C}$ with a stability of \pm $0.5^{\circ} \mathrm{C}$ and homogeneity of $\pm 2 \%$.

The moisture content determinations were made with the Surveymaster model of a Protimeter digital hygrometer.

\subsection{Tests}

The planning of the test phase takes into account the objectives pursued in each test and is divided into several stages.

\subsubsection{Analysis of the influence of wood density upon its surface temperature}

The test sample comprised of 15 pieces from different wood species (oak, poplar, pine, cedar and eucalyptus) with a size of $2 \times 2 \times 30 \mathrm{~cm}$. The average density was determined and the moisture content at test time lay in the range $11-13 \%$ for all pieces, as determined by a digital hygrometer.

In a first test stage, a thermographic image of the pieces was taken at ambient temperature without applying any source of external stimulation, and with a previous correction of the values of emissivity and reflected ambient temperature.

In a second phase, the samples were thermally stimulated in an oven at $80{ }^{\circ} \mathrm{C}$ for 30 minutes. The specimens were then removed from the oven and the cooling process was monitored for 40 minutes by taking thermographic images every 30 seconds. 


\subsubsection{Detección de defectos internos en la madera}

Con el objetivo de analizar el rango de defectos no superficiales que se pueden detectar mediante termografía de infrarrojos se han realizado dos tipos de ensayos en el que se mide la diferencia térmica observada entre la zona del defecto y la madera sana. Por un lado, se ha analizado hasta qué profundidad es posible detectar un defecto interno en la madera y, por otro, para una profundidad dada se ha estudiado el tamaño del mínimo defecto detectable. Asimismo, en una segunda fase del estudio se ha analizado cómo interviene la humedad en el proceso de estimulación de la madera favoreciendo la localización de los defectos.

Para realizar estos ensayos se han preparado dos series de tres probetas cada una de madera de pino silvestre (Pinus sylvestris $L$ ). El corte de las probetas se realiza de manera que la testa de la pieza tiene una sección de 40 x $100 \mathrm{~mm}$ y un contenido de humedad de $6-7 \%$. En cada pieza se ha tallado una perforación simulando un deterioro interno en la pieza. En una primera serie, se han tallado huecos de $4 \times 4 \mathrm{~cm}$ y posicionados a $0,5,1$ y $1,5 \mathrm{~cm}$ (Figura 1) de la superficie. En la segunda serie, manteniendo constante la profundidad de la talla, $0^{\prime} 5 \mathrm{~cm}$, se ha alternado su tamaño desde $1 \times 1 \mathrm{~cm}, 2 \times 2 \mathrm{~cm}$ hasta $4 \times 4 \mathrm{~cm}$ (Figura 2).

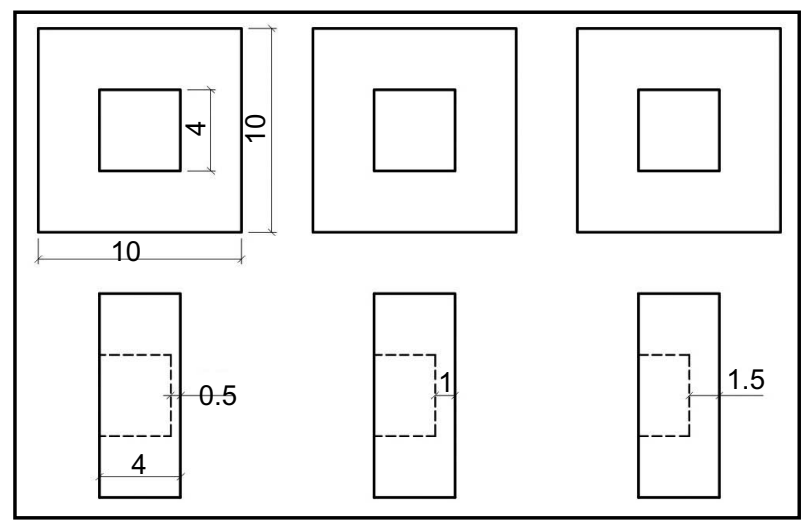

Figura 1. Serie 1. Perforaciones del mismo tamaño situadas a distinta profundidad.

Figure 1. Set 1. Perforations of the same size, situated at different depths.

\section{- Defectos secos}

En esta primera etapa el contenido de humedad es uniforme en la probeta, 6-7\%.

El procedimiento operatorio seguido para las dos series es análogo y se ha subdividido en dos fases. En una primera fase del ensayo, se han tomado las 3 probetas referidas a una misma serie y se han colocado enfrentadas a la cámara termográfica de forma que el deterioro

\subsubsection{Detection of internal defects in wood}

In order to analyse the range of non-surface defects that can be detected by means of infrared thermography, two types of tests were conducted in which the thermal difference was measured as observed between the zone of defects and the healthy wood. In one test, the depth to which it is possible to detect an internal defect was analysed, while in the second test, for a given depth, the size of the minimum detectable defect was studied. Likewise, in a second phase of the study, an analysis was conducted on the effect of the intervention of moisture in the stimulation process of the wood, which favoured the localization of the defects.

For these tests, two sets of three pieces each were prepared in Scots pine (Pinus sylvestris L). The cut of the samples was carried out in such a way that the tests of the piece had a cross-section of $40 \times 100 \mathrm{~mm}$ and a moisture content in the range of $6-7 \%$. A hole of a determined size and depth was cut into each of the samples to simulate internal decay. In a first series, the holes were cut with the same size, $4 \times 4 \mathrm{~cm}$, and positioned at different depths, $0.5,1$, and $1.5 \mathrm{~cm}$ (Figure 1) from the surface. In the second set, the holes were located at a constant depth, $0.5 \mathrm{~cm}$, but their sizes ranged from $1 \times 1 \mathrm{~cm}, 2 \times 2 \mathrm{~cm}$, to $4 \times 4 \mathrm{~cm}$ (Figure 2).

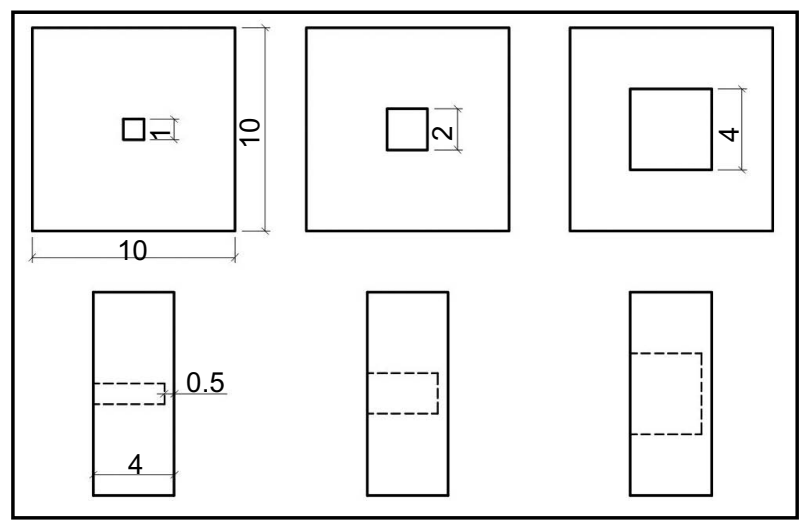

Figura 2. Serie 2. Perforaciones de distinto tamaño situadas a la misma profundidad.

Figure 2. Set 2. Perforations of different sizes situated at the same depth.

\section{- Dry defects}

In the first step, the moisture content is uniform in the sample, 6-7\%.

The same test procedure was followed for the two series and was divided into two stages. In the first phase of the test, three specimens which belonged to the same series were taken and were placed facing the thermographic camera in such a way that the deterioration simulated by 
simulado mediante la talla de la perforación queda oculto en la cara opuesta de cada pieza. La distancia de la cámara a las probetas es 1,20 m. Sin aplicar ninguna fuente de estimulación, termografía pasiva, y, ajustando los parámetros de emisividad y temperatura ambiente reflejada, se ha tomado una primera imagen termográfica del conjunto.

En una segunda fase, se ha aplicado una fuente de estimulación térmica a las piezas, termografía activa, introduciéndolas en una estufa a $80{ }^{\circ} \mathrm{C}$ durante 45 minutos. Seguidamente, se han colocado enfrentadas a la cámara según lo descrito manteniendo constante la distancia de $1,20 \mathrm{~m}$ y se ha analizado su proceso de enfriamiento tomando imágenes termográficas a intervalos constantes. El objetivo de esta fase es medir el contraste térmico entre la zona de la probeta donde se ha mermado su espesor y el resto de la pieza (zona con "deterioro" y zona "sana").

Esta fase del ensayo se ha repetido modificando el procedimiento de estimulación térmica de las muestras. El objetivo que se ha perseguido es tratar de reproducir las circunstancias reales de una obra de rehabilitación donde los elementos de madera no pueden ser trasladados para introducirlos en una estufa y provocar un choque térmico. De esta manera, se han realizado nuevos ensayos en los que la estimulación térmica se ha producido a partir de un foco portátil de $1.500 \mathrm{~W}$ que se ha enfrentado a las probetas.

El procedimiento de ensayo se ha realizado en reflexión, esto es, situando la lámpara empleada para la estimulación térmica interpuesta entre las probetas y la cámara termográfica. La distancia de la cámara a las piezas se ha mantenido constante con respecto a los ensayos anteriores, 1,20 m, y el foco se ha situado a una distancia de las piezas de $35 \mathrm{~cm}$.

Una vez colocados el foco y la cámara para cada caso, se ha iniciado el proceso de calentamiento. A diferencia de los ensayos anteriores, en este ensayo, se ha podido medir el contraste térmico alcanzado durante la etapa de calentamiento entre la zona "sana" y la zona con "defectos" de la probeta. Posteriormente, se ha apagado el foco y se ha realizado el seguimiento del proceso de enfriamiento.

\section{- Defectos húmedos}

Utilizando las dos series de probetas preparadas, se han repetido los ensayos anteriores pero, en este caso, simulando que la zona con defectos presenta un mayor contenido de humedad que el resto de la madera sana de la probeta. Esta hipótesis de partida le aporta realismo al ensayo ya que, normalmente, la madera que está deteriorada con pudrición tiene más humedad que la madera sana. the perforation remained hidden on the other side of the each piece. The distance of the camera to the samples is $1.20 \mathrm{~m}$. Without applying any source of stimulation (passive thermography), and by adjusting the parameters of emissivity and reflected ambient temperature, a first thermographic image was taken of the set.

In a second phase, a source of thermal stimulation was applied to the pieces, (active thermography), by inserting them into an oven at $80{ }^{\circ} \mathrm{C}$ for 45 minutes. The pieces were then placed facing the thermographic camera at a constant distance of $1.20 \mathrm{~m}$, and the cooling process was analysed by taking thermographic images at constant intervals. The purpose of this phase is to measure the thermal contrast between the zone of the sample where its thickness is eroded ant the rest of the piece (the zone with the "deterioration" and "healthy" zone).

This phase of the test is repeated while modifying the thermal stimulation procedure on the samples. In order to reproduce real-life circumstances of a work of rehabilitation where the wooden elements cannot be transferred for their insertion into an oven to cause a thermal shock, new tests were conducted in which the thermal stimulation of the samples was produced by a 1500 W portable lamp.

The test procedure was performed in reflection, that is, the lamp used for thermal stimulation was placed between the sample and the thermographic camera. The distance from the camera to the pieces was maintained constant as in previous tests, at $1.20 \mathrm{~m}$, and the spotlight was situated at a distance of $35 \mathrm{~cm}$ from the pieces.

Once the focus and the camera were placed for each case, the heating process was started. Unlike previous trials, in this test, measurement was made of the thermal contrast reached during the heating step between the "healthy" zone and the area with "defects" of the sample. The spotlight was then switched off and the cooling process was carried out.

\section{- Wet defects}

The above tests were repeated using the two sets of prepared samples, but in this case, it was simulated that the area with "defects" had a higher moisture content than the rest of the (sound) wood of the specimen. This hypothesis brings realism to the test since decayed wood typically has a higher moisture content than sound wood. 
Así, tras saturar de humedad los "defectos" de las piezas introduciendo papel de celulosa empapado de agua, hemos medido la humedad superficial alcanzada en el área del "defecto" y en el resto de la probeta mediante xilohigrómetro digital. Las medidas de humedad se han tomado en la cara interna de las muestras (la opuesta a la enfrentada a la cámara para suponer una humedad interior). Los resultados para las dos series se recogen en la Tabla 1.

La primera fase del procedimiento operatorio del ensayo anterior se ha suprimido (termografía pasiva) y se han tomado, únicamente, las imágenes termográficas tras aplicar la estimulación térmica a las muestras (termografía activa).

Para la segunda fase, se han introducido nuevamente las probetas en la estufa y, repitiendo la metodología de ensayo anterior, se han colocado las piezas enfrentadas a la cámara a una distancia de 1,20 m, ajustando los parámetros de emisividad y temperatura ambiente reflejada. De la misma forma, se ha realizado el seguimiento del proceso de enfriamiento de las probetas analizando, en esta nueva situación, la influencia de un incremento de humedad en la zona del defecto sobre la variación térmica alcanzada entre esta zona y el resto de la pieza.
Hence, after the "defects" were saturated with moisture by introducing cellulose paper soaked in water, the surface moisture content reached in the area of "defects" was then measured and that of the rest of the sample by means of a digital hygrometer. The moisture content measurements were taken on the internal face of the samples (the opposite to that facing the camera in order to suppose interior dampness). The results for the two series are shown in Table 1.

The first phase of the operative procedure of the above test was suppressed, (passive thermography), and only after applying the thermal stimulation to the samples, were the thermographic images taken (active thermography).

For the second phase, the samples were reintroduced into the oven and, repeating the method of the above test, the pieces were placed in front of the camera at a distance of $1.20 \mathrm{~m}$, and the parameters for the emissivity and reflected ambient temperature were adjusted. In the same way, the cooling process of the samples was followed, and, in this new situation, the influence of an increase in the humidity in the "defect" zone on the thermal variation between this zone and the rest of the piece was analysed.

Tabla 1 / Table 1

Medición de contenido de humedad en cada probeta tanto en la zona de defecto como en el resto de la probeta. Measurement of moisture content in each sample in the "defect" zone and in the rest of the sample.

\begin{tabular}{|c|c|c|c|}
\hline \multicolumn{2}{|c|}{ Defecto / Simulated Defect } & \% humedad defecto / \% humidity of "defect" zone & \% humedad probeta / \% humidity of sample \\
\hline \multirow{3}{*}{ Profundidad / Depth } & $0.5 \mathrm{~cm}$ & $26-28$ & $9-11$ \\
\cline { 2 - 4 } & $1 \mathrm{~cm}$ & $26-28$ & $9-11$ \\
\cline { 2 - 4 } & $1.5 \mathrm{~cm}$ & $26-28$ & $9-11$ \\
\hline \multirow{3}{*}{ Tamaño / Size } & $1 \times 1$ & $50-52$ & $9-11$ \\
\cline { 2 - 4 } & $2 \times 2$ & $26-28$ & $9-11$ \\
\cline { 2 - 4 } & $4 \times 4$ & $26-28$ & $9-11$ \\
\hline
\end{tabular}

\subsubsection{Detección del deterioro interno de la madera producido por insectos sociales (termitas)}

Dado que uno de los objetivos propuestos es poder localizar pérdidas de densidad internas provocadas por patologías de origen biótico (termitas), se han tallado varias probetas donde se ha simulado la forma de deterioro particular de un ataque de insectos xilófagos.

Así, se han preparado 6 probetas de madera de pino silvestre exentas de cualquier ataque y agrupadas en dos series. Sobre estas probetas de dimensiones 4,5 x 7,5 $\mathrm{x}$ $4,5 \mathrm{~cm}$ y un contenido de humedad en torno al $8-10 \%$ se han perforado galerías de $0,6 \mathrm{~cm}$ de diámetro y dispuestas como a continuación se detalla. En una primera serie se ha taladrado, en cada probeta, una única columna de galerías situándolas, en cada caso, a una profundidad

\subsubsection{Detection of internal deterioration of wood produced by social insects (termites)}

Given that one of the proposed objectives of this study is to be able to locate internal density losses caused by pathologies of biotic origin (termites), various samples were drilled in order to simulate the form of deterioration peculiar to an attack by xylophagous insects.

To this end, six wooden samples of Scots pine which were exempt from any attack were prepared and grouped into two series. On these samples of dimensions $4.5 \times 7.5 \times 4.5 \mathrm{~cm}$ and of moisture content ranging from 8 to $10 \%$, galleries of $0.6 \mathrm{~cm}$ in diameter were drilled, set out as follows: In the first series, in each sample, a single column of galleries was drilled, in each case, to a different depth from the surface (Figure 3). In a second 
distinta de la superficie (Figura 3) para, en una segunda serie, aumentar progresivamente este número de perforaciones suponiendo una pérdida de densidad superior en cada caso (Figura 4).

El procedimiento operatorio se ha ejecutado en dos fases agrupando las probetas por series. Para ello, en ambas fases, se han colocado las piezas enfrentadas a la cámara termográfica de perfil de modo que, a priori, no es posible apreciar el deterioro representado en las mismas. El objetivo es simular la sección de una viga en la que existen galerías longitudinales provocadas por un ataque de termitas.

En la primera fase del ensayo se ha tomado la imagen termográfica de cada serie sin aplicar fuente de estimulación térmica alguna (termografía pasiva). En la segunda fase, se han introducido las piezas en estufa durante 30 minutos a $80{ }^{\circ} \mathrm{C} y$, posteriormente, se ha analizado su proceso de enfriamiento durante 30 minutos tomando imágenes cada 30 segundos.

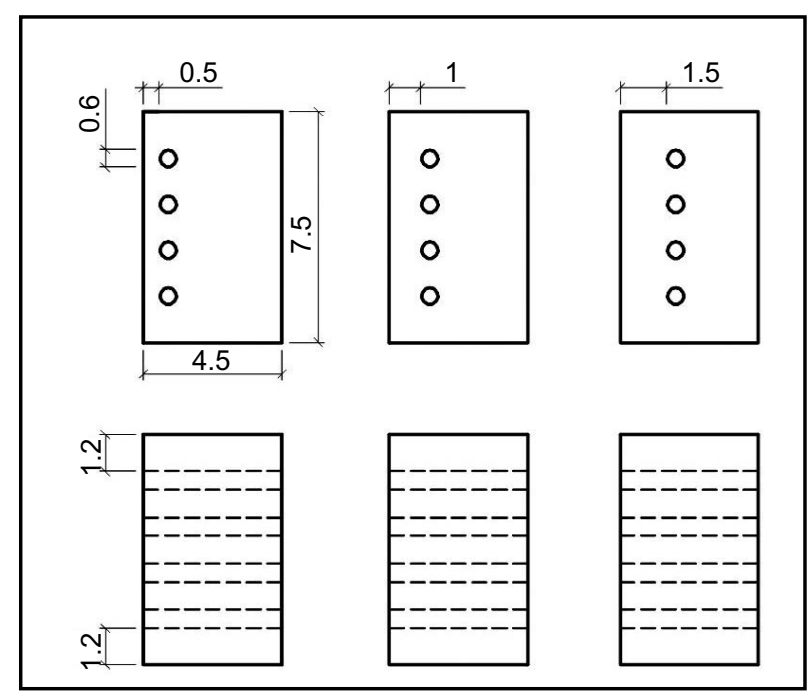

Figura 3. Serie 1. Galerías situadas a distinta profundidad de la superficie.

Figure 3. Series 1. Galleries situated at different depths from the surface. series, the number of holes was increased, thereby assuming a greater loss of density in each case (Figure 4).

The operative procedure was executed in two phases, grouping the samples according to their series. To perform the test, in both phases, the samples were placed in front of the thermographic camera in profile in such a way that, a priori, it was impossible to appreciate their simulated deterioration. The objective is the simulation of a section of a beam in which longitudinal galleries exist caused by a termite attack.

In the first phase of the test, the thermographic image of each series is taken without the application of any source of thermal stimulation, (passive thermography). In the second phase, the test pieces were inserted into an oven for 30 minutes at $80^{\circ} \mathrm{C}$, and the cooling process was then analysed for 30 minutes, whereby pictures were taken every 30 seconds.

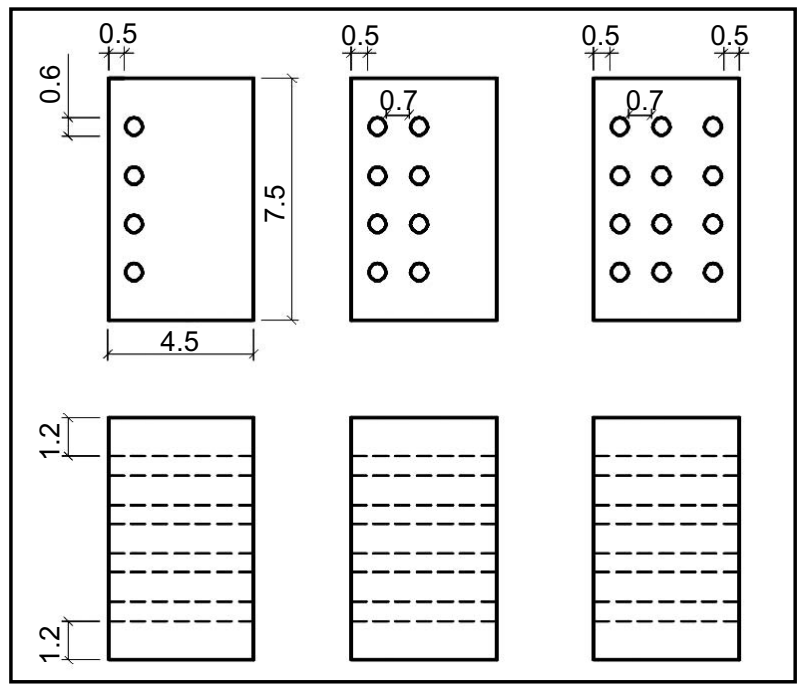

Figura 4. Serie 2. Aumento progresivo de galerías perforadas.

Figure 4. Series 2. Progressive increment of the number 0 $f$ drilled galleries.

\section{RESULTS AND DISCUSSION}

For the analysis and discussion of the results, it should be borne in mind that the range of precision of the camera is $\pm 2{ }^{\circ} \mathrm{C}$, which implies that for tests in which a low thermal contrast is obtained (smaller defects and those away from the surface), the results cannot be used to draw quantitative conclusions although they can be used to draw qualitative conclusions from the point of view of the thermal contrast observed. 


\subsection{Análisis sobre la influencia de la densidad de la madera en su temperatura superficial}

Los resultados del ensayo se recogen en la Tabla 2 . De la primera fase, termografía pasiva, se deduce que, a temperatura ambiente, existe una relación lineal creciente entre la densidad y la temperatura superficial de la madera.

Para la segunda fase del ensayo, termografía activa, se estudia el patrón de enfriamiento y se aportan una serie de ecuaciones con sus coeficientes de determinación que ilustran momentos concretos del proceso de enfriamiento de las muestras. En todos los casos, se observa que las especies con mayor densidad tienen una temperatura superficial más elevada, lo que ratifica el efecto de la densidad sobre la temperatura superficial de la madera.

\subsection{Analysis of the influence of wood density on its surface temperature}

The test results are shown in Table 2. In the first phase, (passive thermography), it is deduced that, at ambient temperature, an increasing linear relationship exists between density and the surface temperature of the wood.

In the second phase, (active thermography), the pattern of cooling is studied and a series of equations with determinant coefficients are provided, which show specific moments of the cooling process of samples. In all cases, it is observed that species with a greater density have a higher surface temperature, which confirms the effect of density on the surface temperature of the wood.

Tabla 2 / Table 2

Resultado del ensayo de Influencia de la densidad de madera en su temperatura superficial $\left(T_{\mathrm{s}}\right.$ temperatura superficial, $\mathrm{d}$ densidad en $\left.\mathrm{Kg} / \mathrm{m}^{3}\right)$. Results of the test of Influence of the density of the Wood upon its surface temperature $\left(T_{s}\right.$ surface temperature, $d$ density in $\mathrm{Kg} / \mathrm{m}^{3}$ ).

\begin{tabular}{|c|c|c|}
\hline Fase / Phase & Ecuación / Equation & $\begin{array}{c}\text { Coeficiente de determinación }\left(\mathbf{R}^{2}\right) / \\
\text { Coefficient of determination }\left(\boldsymbol{R}^{2}\right)\end{array}$ \\
\hline $\begin{array}{c}T^{\mathrm{a}} \text { ambiente / Ambient } T^{\mathrm{a}} \\
\left(26.6^{\circ} \mathrm{C}\right)\end{array}$ & $\mathrm{Ts}=0.0024 \mathrm{~d}+25.387$ & 0.92 \\
\hline $\begin{array}{c}\text { Tiempo de enfriamiento / } \\
\text { Cooling time }\end{array}$ & Ecuación / Equation & $\begin{array}{c}\text { Coeficiente de determinación }\left(\mathbf{R}^{2}\right) / \\
\text { Coefficient of determination }\left(\boldsymbol{R}^{2}\right)\end{array}$ \\
\hline $2^{\prime}$ & $\mathrm{Ts}=0.0872 \mathrm{~d}+26.72$ & 0.96 \\
\hline $10^{\prime}$ & $\mathrm{Ts}=-4 \cdot 10^{-4} \mathrm{~d}^{2}+0.52 \mathrm{~d}-105.43$ & 0.96 \\
\hline $15^{\prime}$ & $\mathrm{Ts}=-5 \cdot 10^{-4} \mathrm{~d}^{2}+0.5898 \mathrm{~d}-129.6$ & 0.97 \\
\hline $20^{\prime}$ & $\mathrm{Ts}=-3 \cdot 10^{-4} \mathrm{~d}^{2}+0.3412 \mathrm{~d}-64.97$ & 0.97 \\
\hline $30^{\prime}$ & $T s=-3 \cdot 10^{-4} \mathrm{~d}^{2}+0.369 \mathrm{~d}-75.825$ & 0.97 \\
\hline
\end{tabular}

\subsection{Detección de defectos internos en la madera}

Los resultados más significativos en los estudios realizados, detección de defectos secos y húmedos, son extraídos en la fase de termografía activa. Estos resultados se recogen en las Tablas 3, 4 y 5. En estas tablas se detallan las ecuaciones obtenidas durante el periodo de enfriamiento de las piezas tras aplicar la estimulación térmica en estufa. Las ecuaciones aportadas cuantifican las diferencias térmicas, $\Delta \mathrm{T}$, a lo largo del tiempo $\mathrm{t}$, entre el área donde se han simulado los defectos y el resto de la madera sana de las piezas. Asimismo se han representado los coeficientes de determinación obtenidos en cada caso.

\section{- Defectos secos}

Los resultados de la primera fase del ensayo (termografía pasiva) se muestran en la Figura 5. El termograma adjunto corresponde a la serie 1 de las probetas (perforaciones del mismo tamaño situadas a distinta profundidad). Como puede observarse, los defectos son imperceptibles en cada una de las piezas independientemente

\subsection{Detection of internal defects in wood}

The most significant results of the studies herein on the detection of dry and wet defects are those provided in the active thermography phase. These results are presented in Tables 3, 4, and 5. These tables set out those equations attained during the cooling period of the pieces previously subjected to thermal stimulation in an oven. The equations quantify the thermal differences, $\Delta T$, over time $t$, between the area where the defects were simulated and the rest of the sound wood of the pieces. In this way, the coefficients of determination obtained in each case are represented.

\section{- Dry defects}

The results of the first phase of the test (passive thermography) are shown in Figure 5. The thermogram corresponds to series 1 of the samples (perforations of the same size situated at different depths). As can be observed, the defects are imperceptible in each of the pieces, no matter their position with respect to the 
de su posición con respecto a la superficie. Para la serie 2 , en la que se altera el tamaño de los defectos desde $4 \times 4 \mathrm{~cm}, 2 \times 2 \mathrm{~cm}$ hasta $1 \times 1 \mathrm{~cm}$ manteniendo constante su posición, el termograma que se obtiene es idéntico quedando, asimismo, ilustrado en la Figura 5. Por tanto, se puede apuntar que, si no se aplica ninguna fuente de estimulación a las muestras, no es posible detectar ningún deterioro interno, independientemente de la profundidad o del tamaño de éstos.

Para la segunda fase del ensayo (termografía activa) los resultados quedan recogidos en la Tabla 3 . En estas expresiones matemáticas se representa la variación térmica, $\Delta T$, entre la zona del defecto y el resto de la pieza ( $T^{\mathrm{a}}$ madera sana de la probeta - Ta defecto) a lo largo del tiempo, t. Estudiando estas expresiones dando valores de tiempo, $t$, se obtiene que las variaciones térmicas máximas en cada caso son: surface. For series 2 , in which the size of the defects varies from $4 \times 4 \mathrm{~cm}, 2 \times 2 \mathrm{~cm}$, to $1 \times 1 \mathrm{~cm}$, maintaining their constant position, the thermogram is identical, and is, in effect, also shown in Figure 5. Hence, it can be noted that if no source of stimulation is applied to the samples, it remains impossible to detect any internal deterioration, regardless of the depth or size of these defects.

For the second phase of the test, (active thermography), the results are presented in Table 3. In these mathematical expressions, the thermal variation, $\Delta T$, is represented between the defect area and the rest of the piece ( $T^{a}$ of sound wood of the sample - Ta of defect area) over time, $t$. By studying these expressions which give values of time, $t$, the maximum thermal variations can be obtained as:

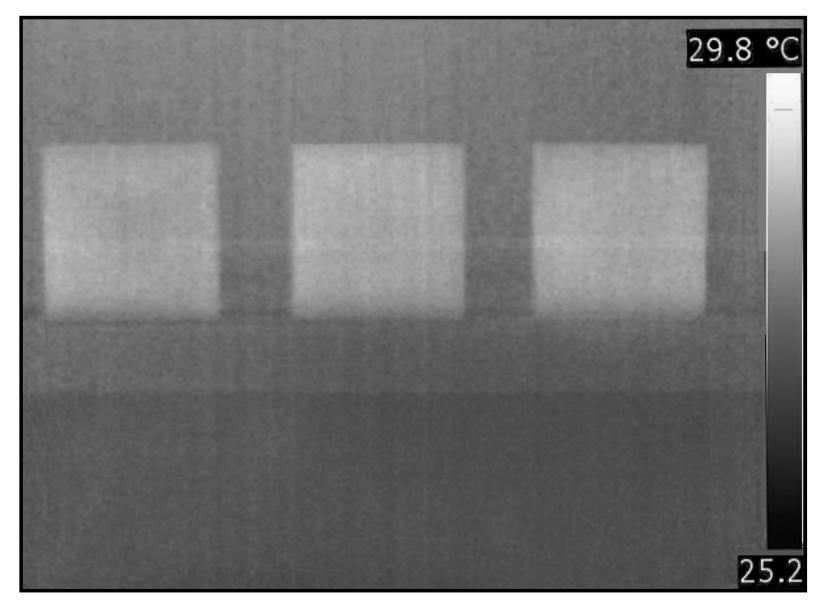

Figura 5. Serie 2. Termograma obtenido para la serie 1 en la fase de termografía pasiva. No es posible diferenciar ningún defecto en ninguna de las probetas independientemente de la profundidad que estos tengan.

Figure 5. Series 2. Thermogram obtained for series 1 in the passive thermography phase. It remains impossible to differentiate any defect in any of the samples regardless of their depth.

Tabla 3 / Table 3

Resultado del ensayo de Detección de defectos internos en la madera (defectos secos). $t$ tiempo en segundos desde que se finaliza la estimulación térmica, $\Delta \mathrm{T}$ incremento térmico en "C medido entre la zona sana de la probeta y la zona con "defecto", ( $T$ a área sana de la probeta - Ta defecto).

Results of the test for the detection of internal defects in the wood (dry defects). $t$ time in seconds from the end of the thermal stimulation, $\Delta T$ thermal increment in ${ }^{\circ} \mathrm{C}$ measured between the sound area of the sample and the zone with "defects", ( $T$ a of sound area of the sample - $T^{a}$ of defect area).

\begin{tabular}{|c|c|c|c|c|c|}
\hline \multirow{13}{*}{ 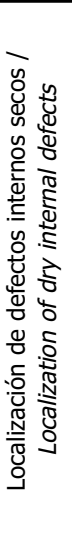 } & \multirow{7}{*}{ 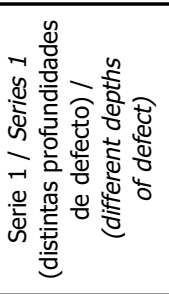 } & \multirow{2}{*}{$0.5 \mathrm{~cm}$} & $\mathrm{t}(0-200 \mathrm{~s})$ & $\Delta T=-2 \cdot 10^{-4} t^{2}+0.0488 t+9.017$ & $R^{2}=0.82$ \\
\hline & & & $\mathrm{t}(200-2400 \mathrm{~s})$ & $\Delta \mathrm{T}=2 \cdot 10^{-6} \mathrm{t}^{2}-0.01 \mathrm{t}+13.399$ & $R^{2}=0.99$ \\
\hline & & \multirow{2}{*}{$1 \mathrm{~cm}$} & $\mathrm{t}(0-400 \mathrm{~s})$ & $\Delta \mathrm{T}=-2 \cdot 10-5 \mathrm{t}^{2}+0.0189 \mathrm{t}-0.1121$ & $\mathrm{R}^{2}=0.96$ \\
\hline & & & $\mathrm{t}(400-2400 \mathrm{~s})$ & $\Delta T=4 \cdot 10^{-7 t^{2}}-0.0029 t+5.3487$ & $R^{2}=0.97$ \\
\hline & & \multirow{3}{*}{$1.5 \mathrm{~cm}$} & $\mathrm{t}(0-400 \mathrm{~s})$ & $\Delta \mathrm{T}=0-$ & \\
\hline & & & $\mathrm{t}(400-1200 \mathrm{~s})$ & $\Delta \mathrm{T}=-2 \cdot 10-6 \mathrm{t}^{2}+0.0041 \mathrm{t}-1.3239$ & $R^{2}=0.75$ \\
\hline & & & $t(1200-2400 s)$ & 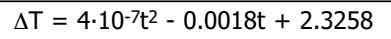 & $R^{2}=0.40$ \\
\hline & \multirow{6}{*}{ 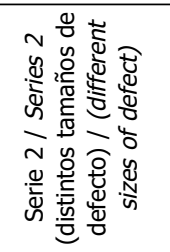 } & \multirow{2}{*}{$4 \times 4 \mathrm{~cm}$} & $t(0-200 s)$ & $\Delta \mathrm{T}=-2 \cdot 10^{-4} \mathrm{t}^{2}+0.0488 \mathrm{t}+9.017$ & $R^{2}=0.82$ \\
\hline & & & $\mathrm{t}(200-2400 \mathrm{~s})$ & $\Delta \mathrm{T}=2 \cdot 10^{-6 \mathrm{t}^{2}}-0.01 \mathrm{t}+13.399$ & $\mathrm{R}^{2}=0.99$ \\
\hline & & \multirow{3}{*}{$2 \times 2 \mathrm{~cm}$} & $t(0-400 s)$ & $\Delta T=-3 \cdot 10^{-5} t^{2}+0.0168 t-0.2087$ & $R^{2}=0.84$ \\
\hline & & & $\mathrm{t}(400-1500 \mathrm{~s})$ & 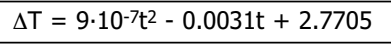 & $R^{2}=0.94$ \\
\hline & & & $t(1500-2400 s)$ & $\Delta \mathrm{T}=0-$ & \\
\hline & & $1 \times 1 \mathrm{~cm}$ & & ibles / No perceptible results & \\
\hline
\end{tabular}


Serie 1:

- Defectos situados a $0,5 \mathrm{~cm}$ de la superficie: $\Delta \mathrm{T}_{\max }=12^{\circ} \mathrm{C} . \mathrm{t}=150 \mathrm{~s}$.

- Defectos situados a $1 \mathrm{~cm}$ de la superficie: $\Delta \mathrm{T}_{\max }=4^{\circ} \mathrm{C} . \mathrm{t}=400 \mathrm{~s}$.

- Defectos situados a $1,5 \mathrm{~cm}$ de la superficie: $\Delta \mathrm{T}_{\max }=0,8^{\circ} \mathrm{C} . \mathrm{t}=1.000 \mathrm{~s}$.

Serie 2:

- Defectos de tamaño $4 \times 4 \mathrm{~cm}$ : $\Delta \mathrm{T}_{\max }=12^{\circ} \mathrm{C} . \mathrm{t}=150 \mathrm{~s}$.

- Defectos de tamaño $2 \times 2 \mathrm{~cm}$ : $\Delta \mathrm{T}_{\max }=2,5^{\circ} \mathrm{C} . \mathrm{t}=300 \mathrm{~s}$.

- Defectos de tamaño $1 \times 1 \mathrm{~cm}$ : $\Delta \mathrm{T}_{\max }=$ sin variación térmica perceptible.

Como se observa las variaciones térmicas máximas se atenúan al aumentar la profundidad de los "defectos" y, para una misma profundidad, al disminuir el tamaño de estos. Asimismo, la posición en el tiempo de estos máximos se alcanza más tarde cada vez al aumentar la profundidad o disminuir el tamaño del deterioro. Para los "defectos" situados a $1,5 \mathrm{~cm}$ se empiezan a registrar leves diferencias térmicas después de un largo proceso de enfriamiento alcanzando un máximo de apenas $1^{\circ} \mathrm{C}$ a los $1.000 \mathrm{~s}$. Por otro lado, los "defectos" por debajo de un tamaño de $2 \times 2 \mathrm{~cm}$ son difícilmente perceptibles siendo imposible localizar aquellos defectos con un tamaño de $1 \times 1 \mathrm{~cm}$.

En todos los casos, la variación térmica (Ta madera sana de la probeta - Ta "defecto"), $\Delta T$, es positiva por lo que la temperatura superficial en la zona del "defecto" es siempre menor que la temperatura en el resto de la probeta. Así, dado que la temperatura superficial en una madera depende del tiempo, de la especie de madera, de la temperatura del aire y de la difusividad (función de la densidad, del calor específico y de la conductividad) (5), y todas estas propiedades son análogas en todas las piezas, este hecho se explica a partir de la diferencia de espesores entre las zonas sanas y con "defectos" dentro de cada pieza. Este factor interviene directamente en la cantidad de calor conducido a través de ellas y conlleva que el calor interior acumulado durante el calentamiento, se disipe más rápidamente para alcanzar la temperatura ambiente.

Los resultados obtenidos en la segunda etapa de ensayo, en la que se han estimulado las probetas mediante el foco portátil, quedan recogidos en la Tabla 4. En este ensayo se han medido las variaciones térmicas alcanzadas, $\Delta \mathrm{T}$, tanto en la fase de calentamiento como, posteriormente, durante el enfriamiento de las mismas. Dando valores a las expresiones matemáticas aportadas obtenemos que las variaciones térmicas máximas en cada fase son:
Series 1:

- Defects situated at $0.5 \mathrm{~cm}$ from the surface: $\Delta T_{\max }=12^{\circ} \mathrm{C} . t=150 \mathrm{~s}$.

- Defects situated at $1 \mathrm{~cm}$ from the surface: $\Delta T_{\text {max }}=4^{\circ} \mathrm{C} . t=400 \mathrm{~s}$.

- Defects situated at $1.5 \mathrm{~cm}$ from the surface: $\Delta T_{\max }=0.8^{\circ} \mathrm{C} . t=1000 \mathrm{~s}$.

Series 2:

- Defects of size $4 \times 4 \mathrm{~cm}$ : $\Delta T_{\text {max }}=12^{\circ} \mathrm{C} . t=150 \mathrm{~s}$.

- Defects of size $2 \times 2 \mathrm{~cm}$ : $\Delta T_{\max }=2.5^{\circ} \mathrm{C} . t=300 \mathrm{~s}$.

- Defects of size $1 \times 1 \mathrm{~cm}$ : $\Delta T_{\max }=$ no perceptible thermal variation.

As can be observed, the maximum temperature variations are attenuated with the increasing depth of the "defects" while, for the same depth, these variations are attenuated with the reduction in their size. Furthermore, these maxima are reached later in time with the increase in depth or decrease in size of the deterioration. For "defects" located at $1.5 \mathrm{~cm}$, mild temperature differences begin to register after a long cooling process with a peak of just $1^{\circ} \mathrm{C}$ at $1000 \mathrm{~s}$. On the other hand, the "defects" below a size of $2 \times 2 \mathrm{~cm}$ remain difficult to perceive, while it is impossible to find those defects with a size of $1 \times 1 \mathrm{~cm}$.

In all cases, the thermal variation ( $T$ a of sound wood of the sample - Ta of "defect" area), $\Delta T$, is positive since the surface temperature in the "defect" zone is always lower than the temperature in the rest of the sample. Hence, since the surface temperature of wood depends on time, wood species, air temperature, and on diffusivity (a function of density, specific heat, and conductivity) (5), and all these properties are similar in all the pieces, this fact is explained from the difference in thicknesses between the healthy areas and those with "defects" within each piece. This factor directly intervenes in the amount of heat conducted through the pieces, and contributes towards the faster dissipation to ambient temperature of the interior heat accumulated during the heating process.

The results obtained in the second phase of the test, in which the samples were stimulated by means of the portable spotlight, are listed in Table 4. In this test, the thermal variations achieved, $\Delta T$, were measured both in the heating phase and, later during the cooling of these specimens. By giving values to the mathematical expressions provided, the maximum temperature variations in each phase are: 
Tabla 4 / Table 4

Resultado del ensayo de Detección de defectos internos en la madera (defectos secos) mediante la estimulación térmica por foco externo. $\mathrm{t}$ tiempo en segundos desde que se finaliza la estimulación térmica, $\Delta \mathrm{T}$ incremento térmico en ${ }^{\circ} \mathrm{C}$ medido entre la zona sana de la probeta y la zona con "defecto", ( $T^{a}$ área sana de la probeta - Ta defecto).

Results of the test for the detection of internal defects in the wood (dry defects) through thermal stimulation by an external spotlight. $t$ time in seconds from the end of the thermal stimulation, $\Delta T$ thermal increment in ${ }^{\circ} \mathrm{C}$ measured between the sound area of the sample and the zone with "defects", ( $T^{a}$ of sound area of the sample - Ta of defect area).

\begin{tabular}{|c|c|c|c|c|c|c|}
\hline \multirow{11}{*}{ 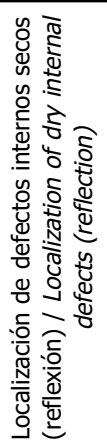 } & \multirow{5}{*}{ 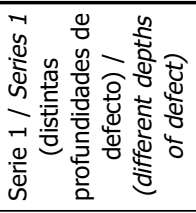 } & $0.5 \mathrm{~cm}$ & $\mathrm{t}(0-200 \mathrm{~s}]$ & CAL. HEAT & $\Delta \mathrm{T}=0$ & - \\
\hline & & & $\mathrm{t}(200-800 \mathrm{~s}]$ & CAL. HEAT & $\Delta \mathrm{T}=3 \cdot 10^{-5} \mathrm{t}^{2}-0.0296 \mathrm{t}+3.9796$ & $\mathrm{R}^{2}=0.88$ \\
\hline & & & $t(800-1600 s)$ & ENF. COOL & $\Delta \mathrm{T}=-1 \cdot 10^{-5} \mathrm{t}^{2}+0.0250 \mathrm{t}-11,5$ & $R^{2}=0.76$ \\
\hline & & $1 \mathrm{~cm}$ & \multicolumn{4}{|c|}{ Sin resultados perceptibles / No perceptible results } \\
\hline & & $1.5 \mathrm{~cm}$ & \multicolumn{4}{|c|}{ Sin resultados perceptibles / No perceptible results } \\
\hline & \multirow{6}{*}{ 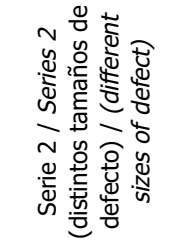 } & $4 \times 4 \mathrm{~cm}$ & $t(0-65 \mathrm{~s}]$ & CAL. HEAT & $\Delta \mathrm{T}=0$ & - \\
\hline & & & $t(0-600 \mathrm{~s}]$ & CAL. HEAT & $\Delta T=7 \cdot 10^{-5} t^{2}-0.0466 t+2.7347$ & $R^{2}=0.86$ \\
\hline & & & $t(600-1400 \mathrm{~s})$ & ENF. COOL & $\Delta \mathrm{T}=-2 \cdot 10^{-5} \mathrm{t}^{2}+0.0418 \mathrm{t}-18.692$ & $R^{2}=0.94$ \\
\hline & & $2 \times 2 \mathrm{~cm}$ & $t(0-600 \mathrm{~s}]$ & CAL. HEAT & $\Delta \mathrm{T}=0$ & - \\
\hline & & & $t(600-1400 s)$ & ENF. COOL & $\Delta T=5 \cdot 10^{-6} t^{2}-0.0123 t+8.5872$ & $R^{2}=0.97$ \\
\hline & & $1 \times 1 \mathrm{~cm}$ & \multicolumn{4}{|c|}{ Sin resultados perceptibles / No perceptible results } \\
\hline
\end{tabular}

\section{- Fase de calentamiento}

Serie 1:

- Defectos situados a $0,5 \mathrm{~cm}$ de la superficie: $\Delta \mathrm{T}_{\text {max }}=-3^{\circ} \mathrm{C}$. $\mathrm{t}=500 \mathrm{~s}$.

- Defectos situados a $1 \mathrm{~cm}$ de la superficie: $\Delta T_{\text {max }}=$ sin variación térmica perceptible.

- Defectos situados a $1,5 \mathrm{~cm}$ de la superficie: $\Delta T_{\max }=$ sin variación térmica perceptible.

Serie 2:

- Defectos de tamaño $4 \times 4 \mathrm{~cm}$ : $\Delta \mathrm{T}_{\max }=-5^{\circ} \mathrm{C} . \mathrm{t}=350 \mathrm{~s}$.

- Defectos de tamaño $2 \times 2 \mathrm{~cm}$ : $\Delta \mathrm{T}_{\max }=$ sin variación térmica perceptible.

- Defectos de tamaño $1 \times 1 \mathrm{~cm}$ : $\Delta \mathrm{T}_{\max }=$ sin variación térmica perceptible.

- Fase de enfriamiento

Serie 1:

- Defectos situados a $0,5 \mathrm{~cm}$ de la superficie: $\Delta \mathrm{T}_{\max }=4^{\circ} \mathrm{C} . \mathrm{t}=1.250 \mathrm{~s}$.

- Defectos situados a $1 \mathrm{~cm}$ de la superficie: $\Delta \mathrm{T}_{\text {max }}=$ sin variación térmica perceptible.

- Defectos situados a 1,5 cm de la superficie: $\Delta \mathrm{T}_{\max }=$ sin variación térmica perceptible.

Serie 2:

- Defectos de tamaño $4 \times 4 \mathrm{~cm}: \Delta \mathrm{T}_{\max }=3^{\circ} \mathrm{C} \cdot \mathrm{t}=1.000 \mathrm{~s}$.

- Defectos de tamaño $2 \times 2 \mathrm{~cm}: \Delta \mathrm{T}_{\max }=3^{\circ} \mathrm{C} . \mathrm{t}=600 \mathrm{~s}$.

- Defectos de tamaño $1 \times 1 \mathrm{~cm}: \Delta \mathrm{T}_{\max }=\sin$ variación térmica perceptible.
- Heating phase

Series 1:

- Defects situated at $0.5 \mathrm{~cm}$ from the surface: $\Delta T_{\max }=-3^{\circ} \mathrm{C} . t=500 \mathrm{~s}$.

- Defects situated at $1 \mathrm{~cm}$ from the surface: $\Delta T_{\text {max }}=$ no perceptible thermal variation.

- Defects situated at $1.5 \mathrm{~cm}$ from the surface: $\Delta T_{\text {max }}=$ no perceptible thermal variation.

Series 2:

- Defects of size $4 \times 4 \mathrm{~cm}$ : $\Delta T_{\max }=-5{ }^{\circ} \mathrm{C} . t=350 \mathrm{~s}$.

- Defects of size $2 \times 2 \mathrm{~cm}$ : $\Delta T_{\text {max }}=$ no perceptible thermal variation.

- Defects of size $1 \times 1 \mathrm{~cm}$ : $\Delta T_{\text {max }}=$ no perceptible thermal variation.

\section{- Cooling phase}

Series 1:

- Defects situated at $0.5 \mathrm{~cm}$ de la superficie: $\Delta T_{\max }=4^{\circ} \mathrm{C} . t=1250 \mathrm{~s}$.

- Defects situated at $1 \mathrm{~cm}$ de la superficie: $\Delta T_{\text {max }}=$ no perceptible thermal variation.

- Defects situated at $1.5 \mathrm{~cm}$ de la superficie: $\Delta T_{\text {max }}=$ no perceptible thermal variation.

Series 2:

- Defects of size $4 \times 4 \mathrm{~cm}: \Delta T_{\max }=3^{\circ} \mathrm{C} . t=1000 \mathrm{~s}$.

- Defects of size $2 \times 2 \mathrm{~cm}: \Delta T_{\max }=3^{\circ} \mathrm{C} . t=600 \mathrm{~s}$.

- Defects of size $1 \times 1 \mathrm{~cm}: \Delta T_{\max }=$ no perceptible thermal variation. 
Durante el transcurso del primer periodo, calentamiento, el contraste térmico observado es negativo ( $T^{\mathrm{a}}$ madera sana de la probeta - Ta "defecto") lo que indica que se alcanza una mayor temperatura en la zona del "defecto". En la segunda etapa, enfriamiento, como en el caso anterior, es la zona del defecto la que observa una menor temperatura.

En este tipo de estimulación térmica y con el foco empleado se han alcanzado unas temperaturas muy altas en un breve espacio de tiempo. Permanecer más tiempo calentando implicaría dañar la madera como de hecho ha ocurrido en algunas probetas por lo que ha tenido que reducir el tiempo de ensayo en gran medida. Se ha intentado estimular las muestras mediante un termoventilador pero el efecto de la convección ha impedido la toma de imágenes durante la fase de calentamiento.

Por otro lado, no se han realizado ensayos en modo de transmisión ya que, debido a las características térmicas de la madera (baja conductividad térmica), sería necesario calentar las piezas durante un largo periodo de tiempo y a una alta temperatura (lo que dañaría la madera) para que el calor alcanzase la cara opuesta de las probetas ( $4 \mathrm{~cm}$ de espesor) desde la que se tomaría la imagen termográfica. No obstante, si se opta por temperaturas más bajas, serían necesarias horas de ensayo para calentar la madera como, de hecho, ocurre en la estimulación térmica natural de las cubiertas mediante el soleamiento.

\section{- Defectos húmedos}

En la Tabla 5 se recogen los resultados obtenidos al humedecer los "defectos" de las probetas. Al dar valores de tiempo $t$, a las expresiones aportadas obtenemos las variaciones térmicas máximas, $\Delta T_{\max }$ ( $T^{a}$ madera sana de la probeta - Ta defecto) que se detallan a continuación:

Serie 1:

- Defectos situados a 0,5 cm de la superficie: $\Delta \mathrm{T}_{\text {max }}=20^{\circ} \mathrm{C} . \mathrm{t}=120 \mathrm{~s}$.

- Defectos situados a $1 \mathrm{~cm}$ de la superficie: $\Delta \mathrm{T}_{\max }=10^{\circ} \mathrm{C} . \mathrm{t}=250 \mathrm{~s}$.

- Defectos situados a $1,5 \mathrm{~cm}$ de la superficie: $\Delta \mathrm{T}_{\max }=2^{\circ} \mathrm{C} . \mathrm{t}=500 \mathrm{~s}$.

Serie 2:

- Defectos de tamaño $4 \times 4 \mathrm{~cm}: \Delta \mathrm{T}_{\max }=20^{\circ} \mathrm{C} \cdot \mathrm{t}=120 \mathrm{~s}$.

- Defectos de tamaño $2 \times 2 \mathrm{~cm}: \Delta \mathrm{T}_{\max }=9^{\circ} \mathrm{C} . \mathrm{t}=150 \mathrm{~s}$.

- Defectos de tamaño $1 \times 1 \mathrm{~cm}: \Delta \mathrm{T}_{\max }=5^{\circ} \mathrm{C} .=800 \mathrm{~s}$.
During the course of the first period, that of heating, the thermal contrast observed is negative ( $T$ a of sound wood of the sample - Ta of "defect" area), which indicates that a higher temperature is reached in the "defect" zone. In the second stage, that of cooling, it is the "defect" zone which shows a lower temperature, as in the previous case.

In this type of thermal stimulation and with the use of a spotlight, very high temperatures were reached in a short space of time. Heating for a longer time would imply damaging the wood as indeed occurred in some samples, which is why test time has had to be reduced significantly. Stimulation of the samples using a fan heater was attempted but the effect of convection impeded images being taken during the heating phase.

Furthermore, no tests have been performed in transmission mode since, due to the thermal characteristics of wood (low thermal conductivity), it would be necessary to heat the pieces over a long period of time and a high temperature (which would damage the wood) so that the heat would reach the opposite side of the specimens ( $4 \mathrm{~cm}$ thick) from which the thermal image would be taken. However, if lower temperatures were chosen, it would take hours of testing to heat the wood as, in fact, occurs in the natural thermal stimulation of the covers by means of sunlight.

\section{- Wet defects}

Table 5 shows the results obtained by wetting the "defects" of the samples. On giving values for time $t$, the maximum temperature variations, $\Delta T_{\text {max }}$ ( $T^{a}$ of sound wood of the sample - Ta of default area), are obtained from the expressions provided, as detailed below:

\section{Series 1:}

- Defects situated at $0.5 \mathrm{~cm}$ from the surface: $\Delta T_{\max }=20^{\circ} \mathrm{C} . t=120 \mathrm{~s}$.

- Defects situated at $1 \mathrm{~cm}$ from the surface: $\Delta T_{\max }=10^{\circ} \mathrm{C} \cdot t=250 \mathrm{~s}$.

- Defects situated at $1.5 \mathrm{~cm}$ from the surface: $\Delta T_{\text {max }}=2{ }^{\circ} \mathrm{C} . t=500 \mathrm{~s}$.

\section{Series 2:}

- Defects of size $4 \times 4 \mathrm{~cm}: \Delta T_{\max }=20^{\circ} \mathrm{C} . t=120 \mathrm{~s}$.

- Defects of size $2 \times 2 \mathrm{~cm}: \Delta T_{\max }=9^{\circ} \mathrm{C} . t=150 \mathrm{~s}$.

- Defects of size $1 \times 1 \mathrm{~cm}: \Delta T_{\max }=5^{\circ} \mathrm{C}$. $=800 \mathrm{~s}$. 
Tabla 5 / Table 5

Resultado del ensayo de Detección de defectos internos en la madera (defectos húmedos). $t$ tiempo en segundos desde que se finaliza la estimulación térmica, $\Delta \mathrm{T}$ incremento térmico en "C medido entre la zona sana de la probeta y la zona con "defecto", ( $\mathrm{T}$ a área sana de la probeta - Ta defecto).

Results of the test for the detection of internal defects in the wood (wet defects). $t$ time in seconds from the end of the thermal stimulation, $\Delta T$ thermal increment in ${ }^{\circ} \mathrm{C}$ measured between the sound area of the sample and the zone with "defects", ( $T^{\mathrm{a}}$ of sound area of the sample - $T^{\mathrm{a}}$ of defect area).

\begin{tabular}{|c|c|c|c|c|c|}
\hline \multirow{12}{*}{ 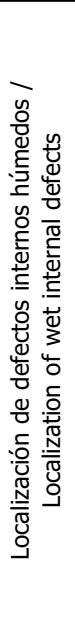 } & \multirow{6}{*}{ 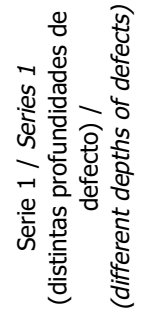 } & $0.5 \mathrm{~cm}$ & $\mathrm{t}(0-200 \mathrm{~s}]$ & $\Delta T=-4 \cdot 10^{-4} t^{2}+0.1018 t+12.92$ & $R^{2}=0.96$ \\
\hline & & & $t(200-3000 s)$ & $\Delta T=2 \cdot 10^{-6} t^{2}-0.0125 t+18.096$ & $\mathrm{R}^{2}=0.97$ \\
\hline & & $1 \mathrm{~cm}$ & $\mathrm{t}(0-700 \mathrm{~s}]$ & $\Delta T=-1 \cdot 10^{-5 t^{2}}+0.0049 t+8.977$ & $\mathrm{R}^{2}=0.82$ \\
\hline & & & $\mathrm{t}(700-3000 \mathrm{~s})$ & $\Delta \mathrm{T}=8 \cdot 10^{-7 \mathrm{t}^{2}}-0.0049 \mathrm{t}+9.3411$ & $R^{2}=0.98$ \\
\hline & & $1.5 \mathrm{~cm}$ & $t(0-1000 \mathrm{~s}]$ & $\Delta \mathrm{T}=1 \cdot 10^{-8 \mathrm{t}^{2}}-0.0011 \mathrm{t}+1.7994$ & $\mathrm{R}^{2}=0.81$ \\
\hline & & & $t(1000-3000 s)$ & $\Delta \mathrm{T}=3 \cdot 10^{-8 t^{2}}+0.0003 t+0.9409$ & $R^{2}=0.54$ \\
\hline & \multirow{6}{*}{ 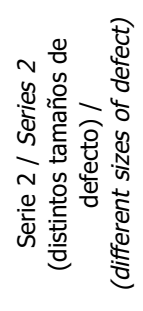 } & $4 \times 4 \mathrm{~cm}$ & $\mathrm{t}(0-200 \mathrm{~s}]$ & $\Delta \mathrm{T}=-4 \cdot 10^{-4 t^{2}}+0.1018 \mathrm{t}+12.92$ & $R^{2}=0.96$ \\
\hline & & & $t(200-3000 s)$ & $\Delta T=2 \cdot 10^{-6 t^{2}}-0.0125 t+18.096$ & $R^{2}=0.97$ \\
\hline & & $2 \times 2 \mathrm{~cm}$ & $t(0-300 s)$ & $\Delta \mathrm{T}=-2 \cdot 10^{-4} \mathrm{t}^{2}+0.0625 \mathrm{t}+3.7586$ & $\mathrm{R}^{2}=0.80$ \\
\hline & & & $t(300-3000 s)$ & $\Delta \mathrm{T}=8 \cdot 10^{-7 \mathrm{t}^{2}}-0.0039 \mathrm{t}+5.5351$ & $R^{2}=0.90$ \\
\hline & & $1 \times 1 \mathrm{~cm}$ & $(0-800 \mathrm{~s}]$ & $\Delta T=-1 \cdot 10^{-5} t^{2}+0.015 t+0.1746$ & $\mathrm{R}^{2}=0.96$ \\
\hline & & & $t(800-3000 s)$ & 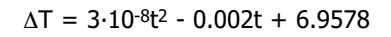 & $R^{2}=0.97$ \\
\hline
\end{tabular}

En todos los casos se observa cómo los contrastes térmicos máximos se acentúan con respecto a la etapa de ensayo anterior en la que tanto la probeta como los defectos contenían la misma humedad (defectos secos). Podemos concluir que estas diferencias son debidas al efecto de enfriamiento evaporativo del agua que hace que la madera humedecida se enfríe más rápidamente incrementando las variaciones térmicas máximas.

\subsection{Detección del deterioro interno de la madera producido por insectos sociales (termitas)}

En este ensayo no se han obtenido resultados reseñables. No se han apreciado diferencias térmicas entre las distintas zonas de las probetas independientemente de la profundidad a la que se sitúan las galerías y/o de su concentración. El pequeño diámetro de las mismas da lugar a que no se produzcan diferencias térmicas significativas. Esto ratifica los ensayos anteriores para las probetas con un tamaño de perforación de $1 \times 1 \mathrm{~cm}$ en las que el contraste era mínimo o imperceptible.

\section{CONCLUSIONES}

De los ensayos realizados puede concluirse:

- Es posible distinguir, a través de la termografía, diferentes tipos de madera como resultado de una diferencia de densidad entre ellas. De esta forma se ratifica el efecto de la densidad de la madera sobre la temperatura superficial.
In every case, it is observed how the maximum thermal contrasts are higher with respect to those of the earlier test phase in which both the sample and the defects contain the same moisture content (dry defects). It can be concluded that these differences are due to the effect of evaporative cooling of the water which makes the wetted wood cool more quickly, thereby incrementing the maximum thermal variations.

\subsection{Detection of internal deterioration of wood produced by social insects (termites)}

In this test, no results of any note have been obtained. There was no appreciable difference in temperature between different parts of the samples regardless of the depth of the galleries and/or of their concentration. The small diameter of these galleries results in the lack of significant temperature differences. This confirms previous tests for the samples with a perforation size of $1 \times 1 \mathrm{~cm}$ in which the contrast was minimal or undetectable.

\section{CONCLUSIONS}

Of the tests performed, it can be concluded:

- It is possible, through thermography, to distinguish between various types of wood as a result of a difference in their density. In this way, the effect of wood density on surface temperature is confirmed. 
- No es posible detectar a través de la termografía pasiva un deterioro interno en una pieza de madera si su contenido de humedad es el mismo que el resto de la madera sana, independientemente de su tamaño y/o profundidad con respecto de la superficie.

- Es posible detectar a través de la termografía activa (estimulación térmica de la madera) defectos internos, con el mismo contenido de humedad que el resto de la probeta, con una profundidad de hasta $1 \mathrm{~cm}$ y con un tamaño mínimo de $2 \times 2 \mathrm{~cm}$.

- Es posible detectar a través de la termografía activa defectos internos húmedos, es decir, con un contenido de humedad superior al resto de la madera sana de la pieza, con una profundidad de hasta $1,5 \mathrm{~cm}$ y un tamaño mínimo de $1 \times 1 \mathrm{~cm}$ debido al efecto del enfriamiento evaporativo del agua.

- No es posible detectar pequeños defectos internos, con el mismo contenido de humedad que el resto de la madera sana, como pequeñas galerías $(0,6 \mathrm{~cm}$ de diámetro) similares a las producidas por insectos sociales (termitas), mediante termografía aunque se aplique una fuente de estimulación externa (termografía activa).

Con todo ello, la termografía se perfila como una técnica de inspección in situ no destructiva que permite localizar defectos superficiales, como nudos debido a una diferencia de densidad entre el nudo y el resto de la madera, y zonas con un distinto contenido de humedad. Para la detección de defectos internos debe emplearse una fuente adicional de calor que estimule las piezas y provoque un contraste térmico entre distintas zonas aunque presenta limitaciones en función del tamaño del defecto y su profundidad.
- It is not possible, via passive thermography, to detect internal deterioration in a piece of wood if its moisture content is the same as the rest of the sound wood, regardless of the size and/or depth of the defect from the surface.

- It is possible, through active thermography, (thermal stimulation of the wood), to detect internal defects which have the same moisture content as the rest of the specimen, at a depth of $1 \mathrm{~cm}$ and a minimum size of $2 \times 2 \mathrm{~cm}$.

- It is possible, through active thermography, to detect wet internal defects, that is to say, defects with a moisture content higher than the rest of the sound wood of the piece, at a depth of up to $1.5 \mathrm{~cm}$ and a minimum size of $1 \times 1 \mathrm{~cm}$, due the effect of evaporative cooling of water.

- It is not possible, through thermography, to detect small internal defects with the same moisture content as the rest of the sound wood and with only small galleries $(0.6 \mathrm{~cm}$ in diameter) similar to those produced by social insects (termites), even if a source of external stimulation (active thermography) is applied.

All things considered, thermal imaging is emerging as a nondestructive in situ inspection technique which facilitates the detection of surface defects, such as knots, due to a difference in density between the knot and the rest of the wood, and the location of areas with a variation in the moisture content. For the detection of internal defects, an additional source of heat should be used for the stimulation of the pieces in order to provoke a thermal contrast between different areas, despite the limitations in terms of the size and depth of the defects.

\section{BIBLIOGRAFÍA / BIBLIOGRAPHY}

(1) Colantonio, A., Gonçalves, M., Gendron P.: Commissioning of exterior building envelopes of large buildings for air leakage and resultant moisture accumulation using infrared thermography and other diagnostic tools. Thermal solutions (2007), pp. 1-12.

(2) Balaras, C. A., Argiriou, A. A.: Infrared thermography for building diagnostics. Energy and buildings, 34 (2002), pp. 171-183.

(3) Clark, M. R., McCann, D. M., Forde, M. C.: Application of infrared thermography to the non-destructive testing of concrete and masonry bridges. NDT\&E International 36 (2003), pp. 265-275. http://dx.doi.org/10.1016/S0963-8695(02)00060-9

(4) Luong, M. P.: Change of thermal images of lumber including knots, finger joints and metal connectors. Bull Kyoto Univ For 69 (1996), pp. 114-128.

(5) Tanaka, T.: Wood inspection by thermography. Wood NTD-2000 - 12th International Symposium on non-destructive testing of wood, vol. 6, no 3 (2000).

(6) Wyckhuyse, A., Maldague, X.: A study of Wood Inspection by Infrared Thermography. Part I: Wood Pole Inspection by Infrared Thermography. Research in Nondestructive Evaluation (2001), pp. 1-12.

(7) Wyckhuyse, A., Maldague, X.: Wood Inspection by Infrared Thermography. Part II: Thermography for Wood Defects Detection. Research in Non destructive Evaluation (2001), pp. 13-21.

(8) Ludwig, N., Redaelli, V., Rosina, E., Augelli, F.: Moisture detection in wood and plaster by IR thermography. Infrared Physics \& Technology vol. 46 (2004), pp. 161-166. http://dx.doi.org/10.1016/j.infrared.2004.03.020

(9) Gilberg, M., Riegel, C., Melia, B.: Leonard J. Detecting Subterranean Termite Activity with Infrared Thermography: A Case Study. APT Bulletin, vol. 34, no 2/3 (2003), pp 47-53. http://dx.doi.org/10.2307/1504822 